\title{
LITERATURE
}

$\infty$

\author{
Emilia Flis
}

UNIVERSITY OF WARSAW

emilia.flis23@gmail.com

\section{The Importance of the Ordinary. Moments of Being in Virginia Woolf's Mrs. Dalloway}

\begin{abstract}
A Sketch of the Past" is an essay in which Virginia Woolf recollects her childhood memories and reflects upon certain events, while trying to understand why she remembers them and forgets others. She mentions the concept "moments of being", though without providing the reader with a clear definition. The idea refers to the bits of our lives in which we experience something beyond the ordinary daily routine - the intense feeling of being alive. The author describes it as "a sudden violent shock; something happened so violently that I have remembered it all my life" (Woolf, A Sketch of the Past 71) and contrasts such intense revelatory moments with "the cotton wool" (70) of non-being that defines most of our living.

The concept "moments of being" is of great importance to the writer, as she herself states: "And so I go on to suppose that the shock-receiving capacity is what makes me a writer" (72). The present article discusses the concept "moments of being" and attempts to capture its meaning by analysing selected passages from one of Virginia Woolf's most famous novels, Mrs Dalloway.
\end{abstract}

Keywords: modernism, time, the ordinary, stream of consciousness, identity, sexuality

One of the characteristics of literary modernism is the focus on the ordinary. When enumerating the features of this period in literary history, in contrast to the Victorian era, Joanna Teske $(2008,58)$ writes in her Philosophy in Fiction: "the characters' inner life (life experience) is of primary importance; meaningful details of life replace the former panoramic vision." Modernist writers shifted the focus from a holistic approach to human existence to quotidian things, daily routine and seemingly unimportant events. They looked at ordinary things from a different perspective and by elaborating 
on them, gave them new meanings. As Terry L. Palls $(1984,64)$ noted, “(...) trivialities acquire importance and the subjective, personal response to them becomes the potential source for instantaneous awareness of the "essence of being."

Virginia Woolf, one of the most prominent modernist writers, also referred to the Ordinary and extensively elaborated on it in her works. Stephen Spender $(1995,185)$ once said that "A new way of writing a book was simply a new way of looking at life for Virginia Woolf: she held life like a crystal which she turned over in her hands and looked at from another angle." When describing common daily life, she noticed something that exists beyond what we know as the usual - the "cotton-wool" of our lives (Woolf, A Sketch of the Past 70). In her essay entitled "A Sketch of the Past" she refers to it as "moments of being" (73); however, she does not define the concept clearly, which is why it is problematic to state what exactly the "moments of being" are. Accurately enough would be to call it as the author herself, namely, "a shock-receiving capacity" (72) - one's ability to notice previously overlooked things, which also involves intense feelings of being alive. The concept "moments of being" is of great importance for Virginia Woolf, as she states: "And so I go on to suppose that the shock-receiving capacity is what makes me a writer" (72). The present article discusses the concept "moments of being" and tries to capture its meaning by analysing selected passages from one of Virginia Woolf's most acclaimed novels, Mrs. Dalloway.

One of the problems Virginia Woolf encountered when producing her works was to present her characters as accurately and credibly as possible. She wanted to depict life as it was and describe not only the most important life-changing events, but also all the things that are usually unnoticed by the individual. The stream of consciousness technique and the subjectivity of narration are the means by which she tried to depict all the aspects of human life.

With reference to modernist writing, in her book Transparent Minds, Dorrit Cohn $(1978,25)$ states: "with the growing interest in the problems of individual psychology, the audible narrator disappears from the fictional world. (...) Even when he passes from centre stage, the narrator continues to narrate, becoming the neutral but indispensable accessory to figure-oriented narration." This kind of narration is used in Mrs. Dalloway. The novel describes a single day from the perspective of a number of characters. With the focus on their thoughts and actions described from their perspective, the reader may observe the shift from the holistic perception of life to what is closer to the individual. The thoughts stand for what is intimate and close to the character, but also for something trivial and unimportant for everyone, except a single person. The third-person narrator disappears, allowing the characters to reveal their true feelings and thoughts. With this more authentic first-person depiction of one's emotions, the reader can identify with the characters, and the presentation of life in the novel gains credibility.

When referring to the events with seemingly little, if any importance, Virginia Woolf used the term "the moments of non-being." These are the parts of life which are not experienced consciously, but rather without the awareness of performing a given activity. As such, they are easily forgotten, as they present no value to the person 
affected; they include the daily routine and all sorts of activities a person is so accustomed to performing that he or she is no longer aware of doing them. Beyond this "nondescript cotton-wool" of everyday life (Woolf, A Sketch of the Past 70), however, there is also something more significant, which becomes a solid part of one's memory. At the beginning of the article, the concept "moments of being" was mentioned. When juxtaposed with the "moments of non-being", the former acquires the meaning of something more significant and important. It would be an event a person recollects; something that makes a long-lasting impact, and, for some reason, is remembered better than other bits of our lives. Because the author provides little information on the subject, it is difficult to find a clear definition of the concept. Woolf only enumerates certain features that the "moments of being" share, for example:

- "Those moments, [...] can still be more real than the present moment" (67).

- "I am hardly aware of myself, but only of the sensation. I am only the container of the feeling of ecstasy, or the feeling of rapture" (67)

- " $[\ldots]$ these moments of being of mine were scaffolding in the background; were the invisible and silent part of my life as a child" (73).

- "Week after week passed at St Ives and nothing made any dint upon me. Then, for no reason that I know about, there was a sudden violent shock; something happened so violently that I have remembered it all my life" (71).

However, enumerating the characteristics of moments of being does not contribute to an understanding of the concept, and its definition remains elusive. It is not known what makes those moments so exceptional and why they evoke such passionate and intense feelings. As, arguably, the way memory works can hardly be influenced, it is difficult to say why only certain things from life are remembered. Woolf herself states that "[u] nfortunately, one only remembers what is exceptional. And there seems to be no reason why one thing is exceptional and another not" (69-70). The author does not focus on explaining her choice of the particular parts of our lives; she simply provides her reader with the depiction of those fragments so as to facilitate the understanding of the concept.

"A Sketch of the Past" consists of Woolf's memories from her childhood. By contrast, in Mrs. Dalloway an additional temporal sphere may be observed, which is introduced by the characters' flashbacks juxtaposed with the present moment. Not only does Virginia elaborate on the revelatory "moments of being" from the past, but she also invites the reader to witness the formation of those intense emotions, as if enabling the readers to participate in the creation of a work of art. This is visible, e.g., when Peter Walsh leaves Regent's Park, thinking about Clarissa. Peter is still very much in love with Mrs. Dalloway; the two used to be very close in their youth, but eventually Clarissa left Peter and married Richard Dalloway. Peter had not recovered from this up to the moment described. However, the passage discussed presents him as a man who started enjoying life itself and realized that he did not need anyone to make the most of life: 
A terrible confession it was (he put his hat on again), but now, at the age of fifty-three, one scarcely needed people any more. Life itself, every moment of it, every drop of it, here, this instant, now, in the sun, in Regent's Park, was enough. Too much, indeed. A whole lifetime was too short to bring out, now that one had acquired the power, the full flavour; to extract every ounce of pleasure, every shade of meaning; which both were so much more solid than they used to be, so much less personal. (Woolf, Mrs. Dalloway 79)

The modernist focus on the individual reveals itself in the utterance of Peter Walsh. He shifts his attention from the outside, the outer world, onto his life and his attitude towards it. By turning to what is general, that is his life in contrast to specific bits and events, he acquires peace and consolation. Life itself is satisfying and, having realised that, one is able to enjoy it despite various obstacles. Peter had been suffering since the loss of his love and could not cope with the pain. Yet after some time, as a middle-aged man, he gained the ability to look at his life from a different perspective and started to notice other pleasant things. The idea that there is much more than pain and disappointment to encounter in the course of our existence is incredibly comforting; the description of Peter Walsh experiencing this "moment of being" omits his physical movement, leaving the sensation and sheer feeling of ecstasy.

Unlike the "moments of being" described in "A Sketch of the Past," the passage above does not represent a form of retelling a past event, but it enables the readers to participate in the creation of an intense feeling. It becomes possible to trace the process of revelation, of sudden awareness of the world surrounding the individual. Peter Walsh is overwhelmed by the possibilities time gives him. He is aware of a number of them, of what can be achieved and what is yet to come. Time no longer "hang[s] heavy on people's hands" (Woolf, Orlando); by creating a sphere of endless possibilities, it becomes a vast source of pleasure.

Time can be also referred to as the creator of the characters. In order to get the most of the present moment, Peter Walsh had to grow older and gain experience. In other words, he had to witness various changes and events in his life in order to be able to look at the world from a different perspective, more holistic and less subjective.

The passage above indicates that in order to experience what Virginia Woolf called a "moment of being", one must be able to look at life from another angle. Growing older and adopting a more general approach to life enables a person to notice what is of real significance for the individual. It is necessary to accept life as it is and find satisfaction in the mere process of life, which is the point that Peter Walsh reached. Disappointed and disillusioned by his vision of life, he decided to change his attitude to reality. His new way of looking at life was provoked by experiencing a "moment of being."

As Virginia Woolf says in "A Sketch of the Past," "moments of being" arrive unexpectedly, with no reason known to the person experiencing the feeling. However, it seems possible to create appropriate circumstances for those moments to appear. These can become visible after the analysis of another passage from Mrs. Dalloway, namely, the moment in which, having returned from shopping for flowers, Clarissa 
rests in her room. Walking slowly upstairs and recollecting memories from her youth, Clarissa is thinking about Sally Seaton and reflecting upon what people call "love." Uninterrupted by others, she is submerged in an intimate zone, which allows her to reveal her true identity. "Women must put off their rich apparel," she states, and having said that, she becomes immersed in her thoughts and introduces herself into a state of trance. In this very moment Clarissa is thinking about Sally and, suddenly, the revelatory moment appears:

She and Sally fell a little behind. Then came the most exquisite moment of her whole life passing a stone urn with flowers in it. Sally stopped; picked a flower; kissed her on the lips. The whole world might have turned upside down! The others disappeared; there she was alone with Sally. And she felt that she had been given a present, wrapped up, and told just to keep it, not to look at it - a diamond, something infinitely precious, wrapped up, which, as they walked (up and down, up and down), she uncovered, or the radiance burnt through, the revelation, the religious feeling! (Woolf, Mrs. Dalloway 35-36)

The memory appears suddenly, for no particular reason. Forgotten in the haste of everyday life, certain events come into being once again, provided the person creates appropriate circumstances for them to reappear. As Virginia Woolf states, "[i]n certain favourable moods, memories - what one has forgotten - come to the top" (Woolf, A Sketch of the Past 67). As shown in the passage, solitude, silence and the state of trance are what the author calls "favourable moods" (Ibid.). Clarissa rests in her room, with no binding duties to perform in the near future. That is why she is able to rest and, at the same time, find delight in thinking about her past.

The event Clarissa recollects is the day on which Sally kissed her. This is the strongest, most intense moment she has ever experienced. By saying that it made others disappear and left her alone with Sally, Clarissa implies that the event had the ability to change reality. So strong was the feeling that she can still feel the emotions it evoked years ago. Keeping it as an unwrapped present prevents it from losing its power to astonish and evoke intense feelings. Calling it a "religious feeling," the author emphasises the sacralised aspect of the memory. When juxtaposed with the present, it acquires additional importance. Here, the "moment of being" is being reflected upon from the perspective of the present and, thus, a certain distance is imposed on the person recollecting the memory and the event itself. Virginia Woolf wonders whether those past memories have an existence of their own: “(...) is it not possible - I often wonder - that things we have felt with great intensity have an existence independent of our minds; are in fact still in existence?" (Ibid.).

Experiencing again such a revelatory moment enables one to live one's life once more. Sitting alone in her room and reflecting upon the idea of love, Clarissa questions what she imagined as this feeling; subconsciously, she also seeks consolation and the means of experiencing such deep emotions once again. She evoked the memory so as to experience the pleasure it provided her with. The "moment of being" described in 
the passage serves as one of the powerful images of Clarissa's past. It somehow comprises all the acts she did in her youth and is unable to do now, because of the role she performs in society. What evokes the "moment of being" in this passage is the feeling of breaking from conventions and binding duties. Being alone in her room, Clarissa is able to get as close as possible to herself, to the essence of being. She no longer has to perform any role or adjust herself to what is appropriate.

Some critics argue the question of Clarissa's homosexuality. One might assume that recollecting Sally's kiss reveals her true identity and enables her to fully embrace her personality. Breaking away from the necessity to hide her sexual preferences is the means by which she experiences her true self. However, there are also critics who claim just the opposite. In Literature and Homosexuality, Michael J. Meyer (2008, 208) states that "Clarissa herself seems somewhat ambivalent about her attachment to Sally." Barbara Rigney claims that Clarissa " (...) wishes to withdraw from what is perceived as a negative, masculine world in which the self can be theoretically violated sexually and psychologically, and to enter a feminine world of flower images and security" (51). The question of Clarissa being a lesbian remains unanswered.

What is common for the two passages mentioned above is the necessity of solitude and quietness to experience the "moments of being." The character has to perform normal activities unconsciously and slide into a state of trance. By doing so, it is possible to create a favourable mood, contrasting with the "nondescript cotton-wool" of a daily life, which enables a person to evoke the revelatory moment. In the case of Peter Walsh, the "moments of being" enabled him to acquire a different attitude towards his life. His sudden awareness of the immensity of life and the opportunities it creates arrived unexpectedly, and its source cannot be explained. What the author emphasises in this fragment is the ability of the "moments of being" to change one's approach to life. The feelings they evoke are so great and intense that they take part in the creation of one's reality and response to the world. It can also be stated that, indeed, they might have an existence independent of our own, and it is only by unknown modes that we can get closer to them to experience our lives once again.

As mentioned above, Clarissa can be perceived as a person who constantly performs different social roles, adjusting her behaviour and responding to the world, depending on the situation. When left on her own and recollecting scenes from the past, "Clarissa is evoking an earlier self who functions as a mirror in which she sees both resemblances and contrasts to her present self" (Dick 36). The contrast seems strong enough to provoke reflection upon who she really is and, at the same time, emphasises the importance of the event described. The contrast mentioned does not present Clarissa's current situation favourably; yet, at the end of the novel, the character experiences another "moment of being" which indicates the opposite. Having left her guests and entered another room, Clarissa finds herself alone, reflecting upon what she has just heard about the man who killed himself. Overwhelmed by the gravity of the situation, she feels terror when trying to embrace her idea of death. But then, the "moment of being" appears, described as follows: 
Pobrane z czasopisma New Horizons in English Studies http://newhorizons.umcs.pl Data: 26/04/2023 11:04:11

The Importance of the Ordinary. Moments of Being in Virginia Woolf's...

Odd, incredible; she had never been so happy. Nothing could be slow enough; nothing last too long. No pleasure could equal, she thought, straightening the chairs, pushing in one book on the shelf, this having done with the triumphs of youth, lost herself in the process of living, to find it, with a shock of delight, as the sun rose, as the day sank. (Woolf, Mrs. Dalloway 185)

The image of death seems bewildering and overwhelming; when juxtaposed with her present situation, it allows her to reflect upon her life and becomes the catalyst of the "moment of being." Septimus's death was a violent act of breaking from conventions and society, something Clarissa yearned to do. Entangled in various duties and social roles, Mrs. Dalloway wanted to experience something beyond the routine and the activities she was used to doing. She would evoke those intense feelings by recollecting her memories, as in the analysis of the previous passage from the book. The subsequent passage introduces a change in Clarissa's attitude and expectations towards life. Shocked by the overwhelming image of death and the sudden break from imposed rules, she starts to find pleasure in her existence, mediocre and ordinary as it may seem. This acceptance is a reflection of Virginia Woolf's own attitude, as it can be found not only in Mrs. Dalloway, but also in other novels, for example, Night and Day. As Mary Datchet, one of the characters, says, "life was a thing one must love to the last fiber of it" (Woolf, Night and Day).

The passage above indicates that Clarissa accepts her position in society. Although her youth might have been filled with rapture and ecstasy flashing beyond the cotton-wool of daily life, she managed to find pleasure in the Ordinary. Just like Peter Walsh, she reached the state of accepting what life gave her and embraced it. Here, the "moments of being" are to confirm oneself in the belief that in spite of various restrictions or the mediocrity of existence, it is possible to find delight in the present moment. One does not need to experience great life-changing events to feel alive. When immersed in the daily routine and the undisturbed flow of non-being, one is able to experience occasional awakenings and the ecstasy they bring. What is necessary to evoke such feelings is the change of perspective in the way a person approaches life. The last passage discussed embraces the qualities of the "moments of being" mentioned earlier in the article. They are provoked by an event from the past but also make one aware of the feeling and allow participation in the process of creating them.

When reading given passages from Virginia Woolf's works, it is possible to note numerous instances of the characters enchanted by remarkable moments. It is the author who decides which events are to be described in a given novel; yet, Woolf mentioned the revelatory ones in her autobiographical essay as well, explaining their importance from the perspective of the present moment. She wanted to keep the most striking and vivid ones in her memory, so as to preserve them and, what is more, to give herself the feeling of sheer pleasure.

By analysing the selected passages from Virginia Woolf's Mrs. Dalloway, the present study tried to capture the meaning of the concept "moments of being", as well as to elaborate on its importance and functions. As its definition remains elusive, anoth- 
er quote may serve as an additional explanation of what has already been said. This passage comes from The Waves, Virginia Woolf's most poetic work. It consists of the internal monologues of six different characters, whose utterances as accurately as possible convey the moments of ecstasy and delight:

"In a world which contains the present moment," said Neville, "why discriminate? Nothing should be named lest by so doing we change it. Let it exist, this bank, this beauty, and I, for one instant, steeped in pleasure. The sun is hot. I see the river. I see trees specked and burnt in the autumn sunlight. Boats float past, through the red, through the green. Far away a bell tolls, but not for death. There are bells that ring for life. A leaf falls, from joy. Oh, I am in love with life!" (Woolf, The Waves 45)

The speaker implies that one should not differentiate between quotidian and remarkable memories, as the Ordinary can be significant, depending on the perspective one looks at it from. Stephen Spender $(1995,185)$ said that Virginia Woolf was able to look at life from another angle and this is precisely what she applied to her novels . The "moments of being" are of great importance for the writer, but also for the readers, because by experiencing them while reading one gets as close as possible to the characters, as well as to Virginia herself.

\section{References}

Cohn, Dorrit. 1978. Transparent Minds: Narrative Modes for Presenting Consciousness in Fiction. Princeton: Princeton University Press.

Dick, Susan. 1989. Virginia Woolf; Building it around one: Mrs Dalloway. New York: Houghton Mifflin Harcourt.

Hill Rigney, Barbara. 1978. Madness and Sexual Politics in the Feminist Novel: Studies in Bronte, Woolf, Lessing, and Atwood. Madison, WI: The University of Wisconsin Press.

Meyer, Michael J. 2000. Literature and Homosexuality. Amsterdam, Atlanta GA: Editions Rodopi B.V.

Palls, Terry L. 1984. "The Miracle of the Ordinary: Literary Epiphany in Virginia Woolf and Clarice Lispector." Luso-Brazilian Review 21 (Summer):64.

Spender, Stephen. 1995. "A Rare Mind and Personality." In Virginia Woolf: Interviews and Recollections, ed. J.H. Stape, 184-186. Iowa City: University of Iowa Press.

Teske, Joanna. 2008. Philosophy in Fiction, Lublin: Maria Curie-Skłodowska University Press.

Woolf, Virginia. 1919a (n.d.) Night and Day. https://ebooks.adelaide.edu.au/w/woolf/virginia/

- 1925 b (1981) Mrs Dalloway, A Harvest Book.

- 1928 c (n.d.) Orlando... https://ebooks.adelaide.edu.au/w/woolf/virginia/

- 1931d (2000) The Waves, Wordsworth Classics

- 1939 e (1985) A Sketch of the Past, A Harvest Book. 